\title{
Environmental Problems and Water Resource Management in Floodplains: Evidence from the Teesta River Basin, Bangladesh
}

\author{
Md. Fakrul IsLaM* and Yoshiro Higano**
}

\begin{abstract}
Environmental problems account for many of the hindrances faced by Bangladesh in her efforts towards economic development. This paper, based on a survey, reflects on the sub-human environmental and socio-economic condition of the people living in the Teesta River basin in Bangladesh, which could have been otherwise had the barrage named Gazoldoba at the upstream of the Teesta River in the Indian territory not been constructed and operated. The Bangladesh authorities had built a barrage in her territory (at Dalia in 1979, at the downstream of the Teesta river) in order to use the Teesta water for irrigation purposes to improve the socio-economic condition of the inhabitants of the Teesta region. However, owing to the controlling of the flow of water at the upstream, the Dalia barrage has become useless. Moreover, there are flash floods, artificial droughts and river erosions in the Bangladesh region, which are caused by controlling of water at Gazoldoba. Therefore, attempts have been made in this study to clearly understand the nature of the problem and to find out an optimal economic solution to it. We have concluded by making some recommendations for optimal use of Teesta water, which would be beneficial for both India and Bangladesh.
\end{abstract}

\section{Introduction}

Water is capable of both giving and taking lives. Now a days, the number of lives lost because of water (sometimes for its over flooding and sometimes for its scarcity) is increasing alarmingly throughout the world. Recently, scarcity of water has gained top priority as an international political agenda. Supply and demand of water has become a major issue in the United Nations General Assembly, and is a central issue in sustainable development in the world arena [20]. The UN's paving the way for the establishment of the World Water Council (WWC) and Global Water Partnership (GWP) proves the greater concern of the world community on the issue of water sharing ([3], [18]).

A panel of experts backed by the World Bank and the United Nations carried out studies covering 500 of the world's major rivers. It noted that the fouling of the water ways and surrounding river basins contributed to a total of 25 million environmental refugees last year, for the first time, exceeding the world's 21 million war related refugees [17]. The World Commission on Water in its report recommends "comprehensive regional planning" for ensuring proper use of water and saving the environment. The people in the south Asian region have been facing the water problem, as many of the rivers flow through more than one country. We must plan our future use of regional water for common interests so that we can

* MESc, Ph.D. Student, Institute of Agricultural \& Forest Engineering, University of Tsukuba

** Ph.D. Professor, Institute of Agricultural \& Forest Engineering, University of Tsukuba 
prepare ourselves ahead of any such catastrophic breakdown. Bangladesh, being the worst sufferer in the sharing of common rivers with India has to pursue a policy based on regional cooperation ([16], [17], [19]). In order to achieve this objective (formulate a policy), we are gathering data on the Teesta River basin area. However, in this paper, we simply focus on the socio-environmental issues and water resource management of the basin through discussion of the result of a survey, and make some recommendations for equitable sharing of the Teesta River water.

\section{From Flood to Scarcity of Water}

At present, more than 430 million people of the world are considered to be distressed by scarcity of water. By 2050, the percentage of world's population living in water scarce countries will increase three to fivefold [6]. The per capita availability of water has fallen in several countries and there is severe concern for potential conflicts regarding use of common water sources. Some countries face severe flooding in the rainy season and severe water crisis in the dry season.

Foreigners, who see video pictures of Bangladesh, taken during June-September, may consider the Bangladeshis as a people who float on water ([4], [11]). However, from November, the land and surface water sources begin to dry up and in March and April, the land becomes cracked and the ground water level drops significantly ([2], [8]). The natural condition in the villages becomes quite opposite to the scene observed during the flood. In order to provide farmers with sufficient irrigation water, the Teesta Barrage Project was implemented by the Bangladesh authorities and started its operation in 1993.

Before the Teesta barrage had started to operate, farmers used ground water for irrigation. But this created environmental problems-excessive iron in cultivable soils, the dropping of water-table etc. The Teesta barrage was built as a part of an irrigation project using the Teesta river water. However, this project has now become useless because of scarcity of water. Though scarcity of water is a worldwide problem, in case of Bangladesh, it should not be so severe, as it is a country of rivers.

\section{Sharing of Teesta Water: Efforts to Mitigate the Problem}

The idea of using the Teesta River for irrigation for the betterment of the people is as old as the British period (1935) [7]. Most of the area found suitable for gravity irrigation falls in the territory of Bangladesh ${ }^{1}$. Due to the partition of India (1947), implementation of the project was delayed ${ }^{1}$. However, afterwards, India and East Pakistan (the name of the Bangladesh territory before independence) started to formulate the project within their own parameters.

Regarding the sharing of the Teesta water dialogues between India and former East Pakistan (now Bangladesh) have been continuing since the 1950s. India kept on demanding different kinds of data for the barrage to be built in the Pakistan side, while proceeding with

1 Under British colonial rule, present India, Pakistan and Bangladesh were recognized as greater India. At the end of the British period (1947), partition of Greater India took place, creating two independent countries-India and Pakistan. At that time, the area of present Bangladesh fell under Pakistan-being termed as East Pakistan. In 1971, Bangladesh became independent through winning the liberation war from Pakistan. 
the construction of a barrage (at Gazoldoba) within her territory. During the 1960s, India and former East Pakistan exchanged the plans of their projects to build barrages on the Teesta [1]. After the liberation war of Bangladesh in 1971, the talks continued but failed to reach a solution. As a result, Bangladesh ended up in getting only 176 cusecs of water in January 1999 [16]. On April $9^{\text {th }}$ and $10^{\text {th }}, 1999$, the Joint River Commission of India and Bangladesh met after observing the 'real situation' but the meeting ended without any significant solution to the problem ([16], [18]).

\section{Review of Literature}

As far as we have gone through, there has not been any research conducted specifically relating to the optimal sharing and use of the Teesta River basin area. However, findings of the studies that we have found to be related with the present study in one way or another are summarized below. We consider that a review of these books and articles will work as background to the issues we have raised in our paper, and also in setting the dimension of our research.

Shaikh Abu Hanif [14] states that, the Teesta river and its adjoining catchment areas are marked by variegated geomorphic process and forms, like the flow of unstable nature, bank erosion and historical course shifting pattern, flood, droughts, siltation and land forms which appear to be the ideal field for that kind of study [14]. He explained hydro-geomorphic characteristics like water discharge, course shifting pattern, water level, duration of floods, sediment characteristics and ground water conditions of the Teesta flood plain. His thesis was completed before the operation of the Gozaldoba barrage. Therefore, issues relating to water sharing were not discussed.

Abbas A.T. [1] mentioned the 'history' of the talks between India and Bangladesh on the establishment of barrages and sharing of the Teesta water (1955-83). During the 1950s, the then East Pakistani authorities intimated the Indian authorities regarding the Teesta Project in her territory. India at that time asked for more detailed data. During the 1960s, India intimated Pakistan about her plan for using the Teesta water and the two parties exchanged information in this regard. India protested against Pakistan's plans to build a barrage, assuming negative effects (inundation's etc.) in her territory. However, Pakistan replied that it was possible for India to use other rivers to irrigate the proposed command area.

After the independence of Bangladesh in 1971, talks on the Teesta water sharing continued in the Indo-Bangladesh Joint River Commission. Bangladesh objected to India's design to divert the water of the Teesta to the Mahanada basin area. The talks continued without any result until 1983, when the two parties reached an adhoc allocation agreement, according to which India was to get 39 percent, Bangladesh 36 percent and the remaining 25 percent was to be reserved for reallocation later, after further study. Abbas A.T. argued that as the irrigation command is overwhelmingly within the Bangladesh territory, Bangladesh should get the lion's share of the water. Moreover, the location of the apportionment had not been specified, which was very important from Bangladesh's point of view in getting the due amount of water [1].

Schachter [13] discussed 'Equitable Apportionment of Freshwater Resources' to some extent. He emphasizes the concept of the 'drainage basin', which implies integral development, giving a high priority to maximization of benefits for the basin as whole, by reducing 
wasteful uses and developing a comprehensive and unified scheme to be followed by all those who are concerned [13]. He also cited some points on the equitable use of world's water resources from the report of the Fifty-second Conference (1966) of the International Law Association held in Helsinki ([9], [10], [14]). These are quite important for the issues raised in this paper (because Bangladesh as a downstream country has the right and seeks an equitable share of her rivers which have originated in the upstream countries). The points which Schacter noted are as follows:

Water utilization of the river basin at present and in the past has to be considered;

The extent to which the population of each basin state is dependent on the river water has to be taken into account;

Research on the comparative costs of alternative means to meet the economic and social needs of the people of the basin states should be carried out;

Care must be taken to avoid unnecessary wastage when utilizing river water;

Availability of other resources has to be considered;

The extent to which compensating one or more of the co-basin states for adjusting conflicting uses is practicable has to be evaluated;

The extent to which the necessities of a riparian state can be met without causing substantial harm to a co-basin state has to be taken into consideration [13].

Herbert Arthur Smith [15] presented cases of controversies related to using rivers (for economic purposes) which run through more than one state. The cases, which he discussed, include the Meuse and its canals, the Zwillikon dam case, the Reo Grande irrigation problem, apportionment of the Nile and 10 others. He drew some general principles. His conclusion was that "In the law of rivers there is no place for any purely legal doctrine derived from any single abstract principle, whether that principle be the absolute supremacy of the territorial sovereign or the old private law doctrine of riparian rights", [15]. Smith called upon all to realize that every system of river forms an indivisible physical unit and to do whatever need to be done (e.g. agreements) to determine and ensure the maximum possible development of the river resources and their equitable distribution between the people concerned (p. 71).

Dimitrios A. Giannias, Joseph N. Lekakis [5] analyzed various aspects of policy model and explained that the surface water resources have becoming scarcer, therefore he insisted the requirement of policies which aim to provide, adequate water supplies for everyone in both national and international context, and sustainable utilization to achieve it.

They argued that, many international river basins are shared without any formal intergovernmental agreement, while bilateral agreements guaranteeing amicable cooperation amount to a handful. They presented a simple economic-ecological model within which they examined input-output controls, social input prices, bilateral water trade, a water market for all water users, and a fixed water allocation agreement as possible water policies for cross border river water sharing. They also argued that, all of these policies could satisfy the conditions for maximum joint economic benefits, while working towards maintaining the functional integrity of river ecosystem [5]. Their analyses indicate that bilateral water trade can prove a workable, efficient and sustainable water policy for a transboundary water allocation of an international river. 


\section{Evidence From a Survey Report}

The current socio-economic condition of the Teesta basin inhabitants (Bangladesh side) is evident from the findings of a survey carried out in 1998 among heads of the households regarding that area.

\subsection{Collection of Data}

The survey was carried out in several Thanas (decentralized administrative areas) of the Teesta River basin area in 1998, using a scheduled questionnaire. The Thanas are Hatibandha and Lalmonirhat Sadar (Lalmonirhat District), Jaldhaka and Dimla (Nilphamari District). Stratified random sampling was used to select the interviewee. The sample error that affected the selection of study sample was 5\% (sampling error at a $95 \%$ confidence level for a stratified random sample was $5 \%$ ).

\subsection{Analysis of Data}

There were two types of data-quantitative and qualitative. The quantitative values were assigned arbitrarily to the item and question responses, and these values were then summed up to obtain total scores of the scheduled questions. Those scores were interpreted as an indicating response of the interviewee. The data set we obtained was categorical (continuous) in nature and we applied general quantification methods. In this research the outside variable data are qualitative in nature and thus we used Microsoft Excel data spread sheet to obtain numerical values of each qualitative responses and then used various statistical calculations.

\subsection{Results and Discussion (Summary of the Survey) :}

The mean number of members per household among the respondents was 6 and most respondents (85\%) were day laborers (working mainly in the agricultural sector). Only 8\% were actual farmers who owned cultivable lands. The approximate yearly income of 89 percent of the respondents was Tk.10,000-20,000 (U\$267) only.

$78 \%$ of the respondents were illiterate, and among children $22 \%$ had been enrolled in primary schools. $7 \%$ of the respondents had completed secondary education and attended colleges. They lived in slum settlements that were made of bamboo, tin and straw. Seventy three percent of the respondents were drinking tube-well water, 29\% were drinking ground well water but most of the people used river water for bathing and dish washing. $92 \%$ of the respondents had no latrine; they used bushes as toilets. The latrines in the area were made of bamboo and straw and there was only one pucca (fully concrete) building. 95\% of the respondents believed that the housing and sanitary condition of the area was unhealthy and not suitable for human habitation.

$89 \%$ of the respondents were found landless and only 11 percent had owned land. The average amount of landholding was 4.45 acres. Only 10 percent of the landowners had personal irrigation machines (shallow pump). Besides shallow pump, farmers used to rent irrigation equipment such as power pump etc. They also used manure and chemical fertilizer for higher yield.

The survey points out that the respondents were not members of any government (GO) 
or Non-government (NGO) development organization. Due to their floating nature and lack of ability to fulfill the conditions adopted by several NGOs (that at least 0.50 acres of land should be owned) the respondents were out of their target group for disbursing loans. All the respondents thought that the most dreadful natural disaster is continuous flood and riverbank erosions. River erosion had degraded their socio-economic status to a condition of poverty and unthinkable misery.

$50 \%$ of the respondents opine that the embankment and barrage made by India over the border is the main cause for sudden flood and bank erosion. All the respondents (who are partially and fully aware of the Teesta Barrage) think that the Teesta Barrage (at Dalia) will bear no fruitful result if India does not obey the International water-sharing pact. They also think that the problem like sudden flood in April or in September is the result of opening the sluice gates to detract excessive water from the Indian portion.

The survey results discussed above paint a quite pitiful picture of the living conditions of the people of the Teesta River basin area (Bangladesh). Below, we propose an optimal solution to the problem.

\section{A Proposal for Solution}

We propose an optimal solution to the problem of sharing of Teesta water especially during the dry season between India and Bangladesh and also some other proposals regarding water management and control during rainy season, which are as follows:

\subsection{An Optimal Sharing Approach to Dry-season Water}

During the 1st phase of implementation of the Teesta barrage (Dalia), using irrigation water, an increasing trend in productivity of land was observed. However, since the commencement of the operation of the Gazoldoba barrage at the upstream, the Dalia barrage project, due to shortage of water, stopped its operation for irrigation. Through the following estimation, we have shown a possible optimal sharing of the Teesta water considering the number of affected people and land productivity of both India and Bangladesh. This sharing can be shown in the figure 3 below: The total land (target area) under the Dalia barrage is $750,000 \mathrm{Ha}$ [7]. The barrage at Dalia point requires at least $40 \%$ of the total water flow in the dry season to remain active. So far, the maximum amount of land $(30 \%$ of the total target area of the Dalia irrigation project) has been cultivated in the year 1996. This cultivation produced crops worth US $\$ 48.86$ million. The sum of the total crop production during the last four years was valued at US\$ 136 million. The total production has drastically decreased in the last two years (1998-1999). The ratio of the Teesta River water in dry season (1998) between India and Bangladesh is exactly 85\% (32,700) and 15\% (4,900 cusecs) respectively ${ }^{2}$. Due to this imbalance in sharing, the Dalia Barrage is practically useless. This can be shown in Figure 1.

Figure 1 portrays an example of optimal sharing. The horizontal axis $\sigma_{l}$ symbolizes a share of Bangladesh. So, $1-\sigma$, (measured to the left from the point 1 ) is the share of India in the context of the Teesta River basin. Left and right vertical axes measure the marginal productivity of water resources in Bangladesh and India respectively.

2 The Daily Ittefaq, January 13, 1998, Dhaka 


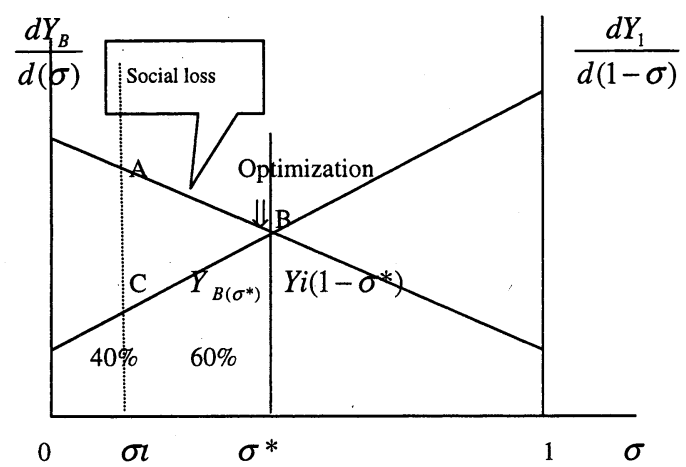

Figure 1: Optimization of Water Sharing between the two Countries

If the share is fixed due to some reason at the level of $\sigma_{l}$ which is far less than the optimal share $\sigma^{*}$, there exists a social loss of the triangle area ABC (the difference lost value of crops in Bangladesh due to the lack of water and the value of crops in India which can be produced by using more water than the optimal sharing) and $\sigma_{l}$ is not optimal from cooperative point of view of both countries in a general sense. If the share increases from $15 \%$ to $40 \%$ then the value of the triangle area can be increased. Economically, an optimal sharing of a fixed amount of resource can be shown at the crossing point of the marginal productivity curves of both parties provided that both the curves are decreasing.

By the figure given above, based on the basic principles of economics, it is possible to show an optimal allocation of fixed resources from economic point of view and we can find optimum sharing points. Although, bilateral politics, law, cooperation etc. can affect the process of bilateral water sharing significantly, Figure 1 gives an easy and simple idea of the whole economic situation in this regard.

However, we must remember that "mutual confidence and cooperation" [5] between the leaders of India and Bangladesh is necessary for an economic policy to be implemented properly. Leaders of both sides have to be sincere in their efforts. They must also have an open mind and be ready to accept rational suggestions given by their counterparts.

\subsection{Integrated Control of Flood Water}

Integrated flood management program have to be planned and implemented for floods during the rainy season, as well as for the flash floods of summer, to save a huge amount of crops and wealth from damage. Early forecasting of floods through remote sensing could help [4]. Unilateral initiative by Bangladesh is not likely to work, because of the geographical situation. Most of the flood water (except rain water) comes to Bangladesh from the upstream, over which she has no control. Therefore, taking into account all related factors -such as rainfall, ice melting, barrage control-an integrated and comprehensive flood control program has to be adopted and implemented.

\subsection{Preservation of Rainy-season Water}

India and Bangladesh can take up a joint program to build reservoirs (as we have seen in the case of Nile water apportionment [15], at the upstream of the Teesta River in India to store the excessive water during the rainy season and share the stored water during the 
dry season. Reservoirs can also be built along the riverside within the Bangladesh territory to store the excessive water during floods, for use during the dry season through gravity irrigation.

\subsection{Bilateral Trade and Business}

For the betterment of the people of the Teesta River basin area (both in India and Bangladesh), we recommend the following:

* While planning and policymaking, emphasis must be placed on an optimal and amicable water sharing and on a suitable trade model ;

* Both Bangladesh and India are recognized as third world countries. So, both the countries should try to cooperate with each other for socio-economic development, rather than engaging in different types of conflicts, and wasting time and resources;

* Considering the number of affected people in both India (8 million) and Bangladesh (21 million) ${ }^{3}$, we can say that, it would be quite consistent with the principle of justice for Bangladesh to get at least $40 \%$ of the Teesta water during dry season;

* Bangladesh should make certain arrangements, for example, to take measures so that Indians, using the Teesta River water (at Dalia or northern districts), can get some opportunities for business and trade in Bangladesh territory;

* Joint ventures (co-project or bilateral agricultural projects) should be encouraged in establishing mills and factories (e.g. rice mills, tobacco husking mills, paper mills, food processing mills) dependent on crops produced in the Teesta region.

However, we must remember that "mutual confidence and cooperation" ([12], [15]) between the leaders of India and Bangladesh is necessary for an economic policy to be implemented properly. Leaders of both sides have to be sincere in their efforts. They must also have an open mind and be ready to accept rational suggestions given by their counterparts.

\section{Conclusion}

Our discussion above suggests that the upstream barrage controls the flow of Teesta water and significantly affects the operation of the down stream barrage. Mitigation of the problem shown in this paper appears to be simple. Efforts like signing of treaties, to solve the problem of water sharing without any appropriate bilateral model of socio-economic development have failed to solve the issue. So far, these efforts did not include the conception of optimal, equitable and the highest possible benefit for the Teesta Basin people as a whole (in India and in Bangladesh). Therefore, the objective of our future research is to assimilate data to formulate an optimal policy model of water sharing and to establish a general theory of using international rivers putting an example of the Teesta River.

\section{References}

[1] Abbas A.T., B.M., The Ganges Water Dispute. 2nd edition. University Press Ltd., 1984.

[2] Alam, Jahangir, "Recent Trend in Agricultural Development of Bangladesh : Policy Implications"

3 According to Bangladesh Bureau of Statistics (BBS 1998) \& Internet. (Internet communication during March 1999 at http://php.indiana.edu./ mduttara/wb/wb.html. 
Economic Observer July 1998, Vol. VIII, No. 5, July 1998.

[ 3 ] Chadwick, M. Soussan, J.G. Alam S. and Malik, D., "From Flood to Scarcity of Water" The Daily Star, June 18, 1999.

[4] Chowdhury, Md. Rashed, Three Essays on Flood Hazard Mitigation: The Case of Bangladesh, unpublished Ph.D. dissertation, Institute of Policy and Planning Sciences, University of Tsukuba, Japan, 1999.

[5] Dimitrios A. Giannias, \& Joseph N. Lekakis, "Policy Analysis for an Amicable, Efficient and Sustainable Inter-country Fresh water Resource Allocation.” Ecological Economics, Vol. 21, Pp. 231-242, 1997.

[6 ] Gardner and Engelman, "Environment Article and Features of Bangladesh" Internet communication on July 10th, 1999, (http://www.beas.net.features/199906/ds18to25.htm).

[ 7 ] Government of the People's Republic of Bangladesh., Teesta Barrage Project July, Vol. IV, Rangpur: Water Development Board (BWDB), 1993.

[8] Government of the People's Republic of Bangladesh, Yearly Manual 1998, Dhaka, Bangladesh Bureau of Statistics (BBS), 1993.

[9] Islam, M. Rafiqul, International Legal Aspects: The Ganges Water Dispute. Dhaka: University Press Ltd. (UPL), 1987.

[10] Lecaros, L. "International Rivers : The Lauca Case", Indian Journal of International Affairs, Vol. 3, No. 8, p-128, 1963.

[11] Rahman, A. Haider R., Haque, S. \&. Jansen, G. Eirck, Environment and Development in Bangladesh, Dhaka: University Press Ltd. (UPL), 1994.

[12] Sadler, B., "Sustainable Development and Water Resources Management". Alternatives Vol. 17 No. 3 Pp. 14-24, 1990.

[13] Schachter, Oscar, Sharing the Worlds Resources. New York: Columbia University Press, 1977.

[14] Shaikh, Abu Hanif, Hydro-Geomorphic Characteristics of the Teesta Flood Plain, Bangladesh; Department of Geography, University of Rajshahi, (Unpublished Ph.D. thesis), 1995.

[15] Smith, H.A., The Economic Uses of International Rivers. London: P.S. King \& Son Ltd., 1931.

[16] Starke, J.G. Introduction to International Law. Tenth edition. London: Butterworth, 1989.

[17] The Daily Ittefaq (January 13, 1998, March 23, 1999 \& January 29, 2000). Bongshal, Dhaka.

[18] The Daily New Nation (December 3, 1999) Dhaka.

[19] The Daily Star, (February 21, 1998). Dhaka.

[20] Virtual Bangladesh, Flood 1998. Grameen Bank, (Internet Communication March 10, at http:// www.virtualbangladesh.com/flood/98), 1998.

[21] The UN General Assembly Resolution No. 2995 (XXVII) and 2996 (XXVII), UN General Assembly Records, 27 ${ }^{\text {th }}$ session (December 15, 1972).

[22] Verghese, B,G., Waters Of Hope ; Academic Publishers, Banglabazar, Dhaka, Bangladesh, p-112, 1990 . 